Jurnal Ekonomi dan Industri

e-ISSN : 2656-3169

Volume 20, No. 2, Mei-Agustus 2019

p-ISSN : 0853-5248

\title{
PEMANFAATAN FITUR \& PRAKTIK TERBAIK SOCIAL MEDIA TERHADAP E-COMMERCE
}

\author{
Wiwik Rachmarwi *) \\ *) Dosen Program Studi Manajemen FE UNKRIS \\ Alamat: Kampus UNKRIS, Jatiwaringin Jakarta Timur \\ E-mail: rachmarwi@gmail.com, wiwikrachmarwi@unkris.ac.id
}

\begin{abstract}
This study aims to examine the use of features and best practices of social media on the Enhancement of E-Commerce, especially Instagram, which can support current trends in online purchasing. In this research is descriptive quantitative. The number of samples used using simple random sampling. The results of this study provide results on Instagram best features and practices that can contribute greatly to the digital economy, e-commerce. Instagram is the perfect social media platform for running an online business, because Instagram has functional features in displaying products, connecting with target customers, and developing broader discussions that make their brands able to offer their ideal customers and by implementing best practices can encourage consumer engagement
\end{abstract}

Keyword: Feature, social media and e-commerce

\section{PENDAHULUAN}

Teknologi yang berkembang sangat pesat bahkan sudah merambah ke semua aspek kehidupan manusia mendorong banyak orang untuk memanfaatkannya kedalam hal berbau ekonomi. Teknologi dan kecanggihan internet sangat membantu manusia dalam memenuhi kebutuhannya. Seperti para inovator yang memanfaatkannya sebagai sarana penjualan segala kebutuhan manusia. Hal ini memicu lahirnya e-commerce atau perdagangan elektronik yang diciptakan untuk transaksi bisnis dengan memanfaatkan internet dan penggunaan web. Semakin dimudahkan dalam melakukan transaksi karena tidak lagi membutuhkan tenaga dan waktu yang lama untuk mencari barang yang kita butuhkan. Esensi dari e-commerce adalah memungkinkan proses jual beli tidak terhalang oleh jarak dan waktu. Aplikasi belanja e-commerce diberi peringkat melalui rata-rata pengguna aktif bulanan (monthly active user - MAU) yang tercatat pada Q1 2019. Memanfaatkan MAU, App Annie Intelligence mengumpulkan dan memberi peringkat aplikasi untuk enam pasar utama di Asia Tenggara (SEA) yaitu, Indonesia, Malaysia, Filipina, Singapura, Thailand, dan Vietnam.

Saat ini perkembangan dalam penggunaan internet mendorong nilai ekonomi digital di Indonesia semakin tinggi. Di Indonesia, terdapat empat sektor yang akan dan terus berkontribusi besar mendorong ekonomi digital yakni e-commerce, media online, ride hailing, dan online travel. Menurut data riset e-conomy SEA 2018, ekonomi digital Indonesia tahun 2018 memperoleh US\$ 27 miliar atau setara Rp 391 triliun. 
Populasi penduduk Indonesia yang besar dan pesatnya pertumbuhan pengguna internet, mendorong masyarakat untuk menggunakan media sosial seperti instagram dan facebook meningkat sebesar 20 persen pada tahun 2019, yaitu mencapai 150 juta pengguna. Salah satu media sosial yang banyak digunakan oleh masyarakat Indonesia adalah Instagram yang dirilis tahun 2010, dimana dalam aplikasi ini pemilik akun dapat mengunggah foto yang bisa diedit dengan berbagai filter.

Dengan berjalannya perkembangan dunia digital, instagram tidak berhenti melakukan terobosan-terobosan dalam hal jejaringan sosial berbasis foto dan video. Saat ini, instagram merupakan salah satu aplikasi yang paling populer.

Berikut adalah empat peringkat terbesar pengguna Instagram di dunia, yaitu: 1). Amerika Serikat dengan pengguna total 110 juta atau $33.44 \%$ total populasi. 2). Brasil dengan pengguna total 66 juta atau $31.38 \%$ total populasi. 3). India dengan pengguna total 64 juta atau $4.68 \%$ total populasi. 4). Indonesia dengan pengguna total 56 juta atau $20.97 \%$ total populasi.

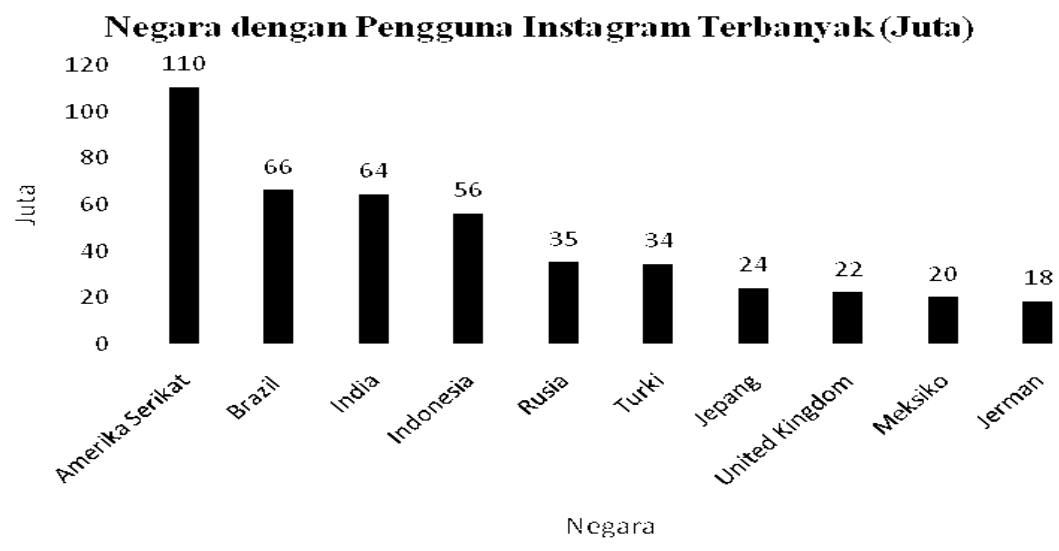

\section{Gambar 1. Grafik Negara Pengguna Instagram Terbanyak Sumber: www.hitekno.com (Januari 2019)}

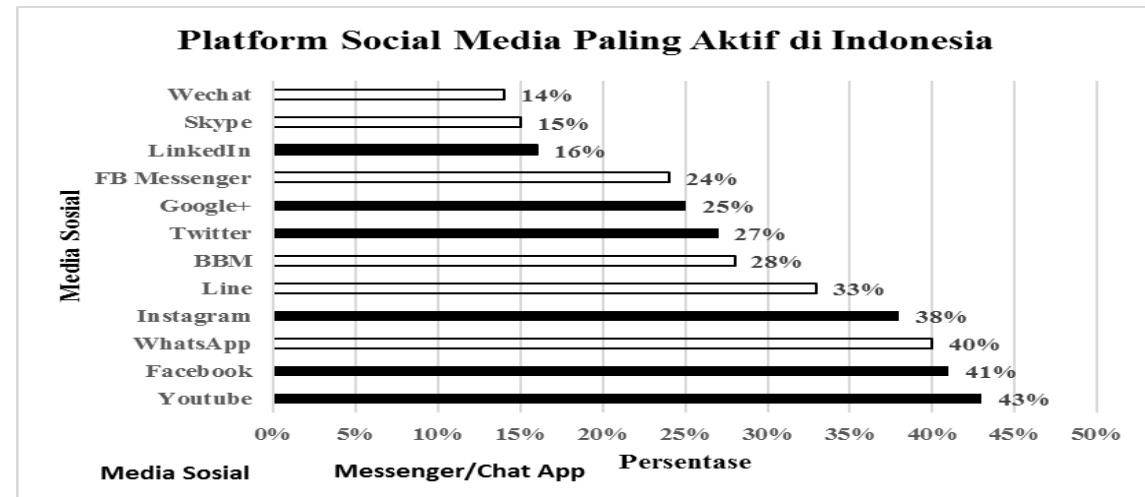

\section{Gambar 2. Grafik Platform Social Media Paling Aktif di Indonesia Sumber: We are Social (Januari 2018)}

Data sampai dengan bulan Januari 2019 peringkat empat besar platforms media sosial yang paling aktif di akses oleh pengguna internet Indonesia adalah youtube (88\%), whatsupp (83\%), facebook (81\%), dan instagram (80\%). Mengapa menggunakan instagram untuk bisnis? Karena sudah terbukti layak bisnis. Sebagaimana dicatat oleh 
statistik bisnis instagram, baik untuk perusahaan global, atau untuk bisnis mom-dan-pop. Instagram makin agresif masuk ke dunia e-commerce, dimana sebelumnya instagram telah mengumumkan mereka meluncurkan fitur agar para pebisnis online di instagram bisa menaruh harga pada produk yang mereka poskan di media sosial itu. Fitur ini memungkinkan pengguna menelusuri, membandingkan harga, dan memesan barang yang diinginkan langsung dari aplikasi instagram di smartphone. Pengguna pun tidak perlu lagi memakai aplikasi chat berbeda seperti whatsapp atau line untuk memesan barang.

\section{LANDASAN TEORI}

\section{Sosial Media}

Interaksi sosial di world wide web, termasuk pola perilaku dan budaya orang yang menggunakan perangkat lunak sosial, dapat digambarkan sebagai media sosial. Perangkat lunak sosial mewakili kelas yang signifikan dari aplikasi "Web 2.0" yang dapat bertindak sebagai mediator untuk komunikasi interpersonal dan pertukaran informasi (Evans 2008, hlm. 33-34). Alat daring yang digunakan orang untuk berbagi konten, profil,opini, wawasan, pengalaman, perspektif, dan bentuk media lainnya, sehingga memfasilitasi percakapan dan interaksi online antara kelompok orang, dapat digambarkan sebagai perangkat lunak sosial. Alat-alat ini termasuk weblog, papan pesan, grup,podcast, microblog, lifestreams, bookmark, jaringan, komunitas, wiki, dan blog video (Solis 2007). Tepper (2003) menegaskan bahwa pengembangan perangkat lunak sosial telah ditingkatkan dengan peningkatan besar dalam jumlah individu yang menggunakan perangkat lunak sosial. Implementasi alat-alat ini dalam lingkungan perusahaan disebut sebagai Enterprise 2.0.

Karakteristik menonjol dari perangkat lunak sosial adalah dasar dari jejaring sosial online antara pengguna. Jaringan pribadi pengguna kehidupan nyata yang ada membentuk dasar untuk membangun jaringan pada platform perangkat lunak sosial. Dengan demikian, jaringan pribadi online dapat mewakili konteks dunia nyata termasuk interaksi sosial dengan menggunakan perangkat lunak sosial dan tumpang tindih dengan interaksi di dunia fisik. Disisi lain, perangkat lunak sosial memungkinkan pengguna untuk membangun hubungan yang sepenuhnya baru secara online.

Karakteristik hubungan ini tergantung pada jenis perangkat lunak sosial dan layanan yang tersedia. Layanan yang disediakan adalah untuk penggunaan komunikasi interpersonal atau grup, dukungan manajemen metadata, informasi dan fungsi pencarian pengguna, publikasi, berbagi, berlangganan, berkomentar, dan kolaboratif

klasifikasi. Mereka pada akhirnya memungkinkan pengguna individu untuk menautkan, bertukar, dan mengatur informasi sebagai bagian dari konten dengan kontak terpilih di jejaring sosial berdasarkan perangkat lunak sosial (Lehel 2007).

\section{Fitur Sosial Media}

Media sosial memiliki banyak fitur menguntungkan daripada media tradisional. Fitur-fitur ini berasal dari teknologi media sosial. Ada empat karakteristik, seiring dengan perkembangan media sosial yang terus menguat. Makalah ini menerapkan teori intelijen untuk mendekonstruksi fitur media sosial, karena media sosial adalah bagian dari rantai informasi. 1). Integrasi; Media sosial menghubungkan pengguna di seluruh dunia, sehingga mereka dapat bertukar dan berbagi informasi dengan platform yang sama. Integrasi adalah kehadiran teori dunia kecil dan prinsip distribusi sebaran. Fitur ini berasal dari teknologi integrasi informasi seperti protokol TCP / IP Teknologi integrasi informasi memberikan jaminan efektif untuk informasi heterogen, platform dan terminal untuk mencapai 
interkoneksi, ini mempersingkat jalur informasi terpendek, dan lebih baik mendukung pengguna untuk mempertahankan "ikatan yang kuat" dan memperluas "hubungan lemah" dari media sosial. Integrasi pengguna dan sumber daya informasi menunjukkan fenomena Matthew di media sosial. 2). Efektivitas Waktu; Pengguna media sosial dapat mengirim dan menerima informasi segera kapan pun mereka mau, yang berarti sinkronisasi pertukaran informasi dan pengguna dapat dengan cepat mengakses informasi yang diperlukan. Efektivitas waktu adalah ukuran dari indikator penting nilai kecerdasan. Karena itu informasi media sosial bernilai tinggi, yang akan banyak menarik pengguna. Inilah keunggulan faktor karakteristik. Teknologi komputer, teknologi terminal seluler, dan teknologi jaringan akan berkecepatan tinggi, broadband, cerdas, arahan mudah, sehingga terus meningkatkan efektivitas waktu media sosial. 3). Sedikit Upaya; Media sosial hampir terbuka dan gratis untuk digunakan, pengguna tidak memerlukan keterampilan khusus atau pelatihan khusus dapat dengan mudah menggunakan media sosial. Semua teknologi yang digunakan di media sosial adalah untuk membantu pengguna membuat upaya paling sedikit untuk mendapatkan dan memanfaatkan informasi, dan yang merupakan pendorong media sosial. Teknik pengambilan informasi media sosial dapat meningkatkan "kekuatan tunggal" media sosial untuk meningkatkan efisiensi akses dan penggunaan informasi. Ini akan memecah keseimbangan kondisi pembangunan, membuat media sosial dari tahap eksplorasi ke tahap pengembangan. 4). Ketertiban; Seperti yang kita ketahui, karena media sosial WEB2.0 bersifat terbuka dan dinamis. Jika kita menganggap media sosial sebagai suatu sistem, ini akan cocok dengan prinsip ilmu informasi dalam teori "struktur disipatif" "sistem terbuka dan dinamis akan secara spontan mengubah bentuk keadaan kacau dan kacau menjadi jenis ruang baru dan fitur yang dipesan. Pengguna massal dan informasi di media sosial, jadi ini akan memberikan banyak aliran entropi ke dalam sistem pengetahuan media sosial, dan yang akan membuat sistem media sosial mencapai keseimbangan atau membentuk sistem pengetahuan baru. Jadi akumulasi, regenerasi dan penuaan intelijen media sosial, dibandingkan dengan media tradisional, lebih cepat. Ini juga bisa menjelaskan fenomena kekacauan dan ketertiban media sosial, yang mencerminkan mekanisme swadaya informasi media sosial. Pengguna media sosial dapat mengedit dan merevisi informasi, informasi yang salah dan tidak berguna di media sosial akan disaring. Penggunaan kreativitas manusia dan kecerdasan biasa itu sendiri untuk menjadikan seluruh informasi media sosial lebih berharga.

\section{Praktik Terbaik Sosial Media}

Menurut Shift Communications (2012) - sebuah agen layanan media sosial, penting untuk transparan, menulis konten sosial berdasarkan keahlian seseorang, dan bijaksana dalam menangani ketidaksepakatan atau konflik di media sosial. Pengalaman praktis dari Social Fresh, sebuah perusahaan pelatihan media sosial, menunjukkan bahwa tujuan untuk keterlibatan, harapan untuk perilaku online karyawan, dan perlindungan informasi rahasia dan hak milik sangat penting untuk mengelola program media sosial di perusahaan, di (Creed 2010). Juga direkomendasikan bahwa media sosial harus digunakan untuk menciptakan kesadaran merek dan reputasi sebelum media tersebut digunakan untuk menjual, menghasilkan pendapatan, dan mendorong advokasi merek (Awareness 2012).

Selain itu, pengalaman praktis dari kodak, dalam menggunakan media sosial facebook dan twitter untuk pemasaran, menemukan bahwa lebih efektif dan lebih mudah untuk dekat dengan pelanggan potensial dengan memberikan ceramah pribadi daripada ceramah pemasaran, sering mengirim pesan atau pembaruan baru, memberikan wawasan tambahan dan menambahkan varietas ke situs sosial dengan tautan eksternal (Eastman Kodak 2009). Untuk memeriksa praktik terbaik media sosial yang disebutkan, studi ini 
melihat seluruh sejarah halaman penggemar instagram masing-masing penjual. Praktik dan aktivitas media sosial mereka di halaman follower instagram, dengan teks, artefak, dan dokumen tertulis, seperti 1). apa yang mereka lakukan dan miliki di halaman penggemar, 2). apa yang biasanya mereka tulis dalam sebuah posting, 3). bagaimana mereka mempresentasikan pesan mereka, 4). seberapa sering mereka memperbarui konten, menanggapi pertanyaan dan kritik, dan mendorong umpan balik dari para penggemar, dan 5). bagaimana mereka mengelola halaman penggemar (kebijakan) dan para penggemar, dipelajari dan dicatat. Jenis konten dan analisis dokumen ini penting untuk menafsirkan pengalaman media sosial nyata perusahaan dan penggemarnya, c.f. (Hodder 2000).

Penerapan praktik terbaik dalam mengelola media sosial oleh penjual, seperti dibahas di atas, telah menciptakan banyak manfaat bisnis, misalnya, peningkatan interaktivitas dan keterlibatan mereka dengan pelanggan dan follower, loyalitas pelanggan, kesadaran merek, dan kesan (Mershon 2011). Beberapa manfaat bisnis ini pada akhirnya mengarah pada hasil bisnis yang lebih baik dalam hal volume penjualan online dan offline dan meningkatkan laba atas investasi (Keath 2012).

\section{E-commerce}

E-commerce mengacu pada penggunaan sarana dan teknologi elektronik untuk melakukan perdagangan (penjualan, pembelian, transfer atau pertukaran produk, layanan, dan / atau informasi), termasuk dalam interaksi bisnis, bisnis ke bisnis, dan bisnis ke pelanggan. Pengiriman ke produk atau layanan dapat terjadi melalui atau di luar internet (Whinston, Choi, dan Stahl, 1997)

Terkadang istilah E-commerce dan e-business digunakan secara bergantian tetapi merupakan konsep yang berbeda. e-commerce adalah istilah yang digunakan untuk menggambarkan proses transaksi bisnis melalui internet. $e$-business, di sisi lain melibatkan rekayasa ulang mendasar dari model bisnis ke dalam jaringan berbasis internet. Perbedaan dalam dua istilah adalah sejauh mana organisasi mengubah operasi dan praktik bisnisnya melalui penggunaan internet (Hackbarth \& William, 2000; Mehtensb, Cragg, dan Mills, 2001; Poon, 2000; Poon and Swatmant, 2007

Saat ini, beberapa waktu setelah 'revolusi dot com / internet', perdagangan elektronik (e-commerce) tetap menjadi bidang manajemen bisnis dan teknologi informasi yang relatif baru, terus berubah. Telah ada dan terus menjadi publisitas dan diskusi tentang ecommerce. Katalog dan rak perpustakaan dipenuhi dengan buku dan artikel tentang masalah ini. Namun, masih ada rasa kebingungan, kecurigaan dan kesalahpahaman di sekitar area, yang telah diperburuk oleh berbagai konteks di mana e-commerce digunakan, ditambah dengan berbagai kata kunci dan akronim terkait.

Untuk memahami e-commerce, penting untuk mengidentifikasi berbagai istilah yang digunakan, dan untuk menilai asal dan penggunaannya. Perdagangan elektronik adalah berbagi informasi bisnis, menjaga hubungan bisnis, dan menjalankan bisnis transaksi melalui jaringan telekomunikasi. Dia mempertahankan bahwa dalam bentuk paling murni, perdagangan elektronik telah ada selama lebih dari 40 tahun, berasal dari transmisi pesan elektronik selama Berlin Airlift pada tahun 1948. Dari ini, Electronic Data Interchange (EDI) adalah yang berikutnya tahap pengembangan e-commerce. Pada 1960-an upaya koperasi antara kelompok-kelompok industri menghasilkan upaya pertama di elektronik umum format data. Formatnya, bagaimanapun, hanya untuk pembelian, transportasi dan data keuangan, dan digunakan terutama untuk transaksi intra-industri. Tidak sampai akhir 1970-an pekerjaan dimulai untuk nasional

Standar Electronic Data Interchange, yang berkembang dengan baik menjadi awal 1990-an. EDI adalah transfer elektronik dari transaksi bisnis standar antara komputer 
pengirim dan penerima, melalui beberapa jenis jaringan pribadi atau Value Added Network (VAN). Kedua belah pihak harus memiliki perangkat lunak aplikasi yang sama dan data akan ditukar dalam format yang sangat ketat. Di sektor-sektor seperti ritel, otomotif, pertahanan, dan manufaktur berat, EDI dikembangkan untuk mengintegrasikan informasi di seluruh bagian yang lebih besar dari rantai nilai organisasi dari desain hingga pemeliharaan sehingga produsen dapat berbagi informasi dengan desainer, pemeliharaan, serta mitra dan pemangku kepentingan lainnya.

\section{Kategori E-Commerce}

Ada empat jenis utama model e-niaga yang dapat menggambarkan hampir setiap transaksi yang terjadi antara konsumen dan bisnis. 1). Business to Consumer (B2C); Ketika bisnis menjual barang atau jasa kepada konsumen individu (contoh. membeli sepasang sepatu dari pengecer online). 2). Business to Business (B2B); Ketika bisnis menjual barang atau layanan ke bisnis lain (contoh: bisnis menjual perangkat lunak sebagai layanan untuk digunakan bisnis lain). 3). Consumer to Consumer (C2C); ketika seorang konsumen menjual barang atau jasa ke konsumen lain (contoh:kita menjual furnitur lama di eBay ke konsumen lain). 4). Consumer to Business (C2B); ketika seorang konsumen menjual produk atau layanan mereka sendiri ke bisnis atau organisasi (mis. Influencer menawarkan pemaparan kepada pemirsa daring mereka dengan imbalan biaya, atau seorang fotografer melisensikan foto mereka untuk digunakan oleh bisnis).

\section{Contoh E-commerce}

E-commerce dapat mengambil berbagai bentuk yang melibatkan hubungan transaksional yang berbeda antara bisnis dan konsumen, serta berbagai objek yang dipertukarkan sebagai bagian dari transaksi ini. 1). Ritel: Penjualan produk oleh bisnis langsung ke pelanggan tanpa perantara. 2). Grosir: Penjualan produk dalam jumlah besar, seringkali ke pengecer yang kemudian menjualnya langsung ke konsumen. 3). Drop shipping: Penjualan produk, yang diproduksi dan dikirim ke konsumen oleh pihak ketiga. 4). Crowd funding: Pengumpulan uang dari konsumen sebelum produk tersedia untuk meningkatkan modal awal yang diperlukan untuk membawanya ke pasar. 5). Berlangganan: Pembelian berulang suatu produk atau layanan secara otomatis sampai pelanggan memilih untuk membatalkan. 6). Produk fisik: Barang berwujud apa pun yang membutuhkan inventaris untuk diisi kembali dan pesanan dikirimkan secara fisik kepada pelanggan saat penjualan dilakukan. 7). Produk digital: Barang digital, templat, dan kursus yang dapat diunduh, atau media yang harus dibeli untuk dikonsumsi atau dilisensikan untuk digunakan. 8). Layanan: Keterampilan atau serangkaian keterampilan yang diberikan sebagai ganti kompensasi. Waktu penyedia layanan dapat dibeli dengan biaya.

\section{METODE PENELITIAN}

Untuk penentuan pengaruh penggunaan instagram pada intensitas pembelian, data primer diperoleh dari distribusi kuesioner yang menggunakan skala Likert. Responden penelitian ini adalah pengguna instagram yang mengikuti akun resmi merek perusahaan dan pengguna Instagram pada umumnya. Sampel sebanyak 120 responden diperoleh dengan menggunakan teknik purposive sampling. 


\section{HASIL DAN PEMBAHASAN}

\section{Karakteristik Responden}

Data responden yang disajikan pada Tabel 1 menegaskan bahwa responden laki-laki merupakan 40 persen dari total responden dan responden perempuan adalah 60\%; bahwa sebagian besar responden berada pada usia 21-30 (37,5\%); bahwa bagian dominan dari responden terdiri dari karyawan swasta, yang merupakan 35,83\% dari total responden; sebanyak 55\% responden memiliki gelar sarjana dan bahwa sebagian besar responden $(44,17 \%)$ telah melakukan belanja online 6-10 kali dalam dua bulan terakhir.

Tabel 1 Karakteristik Responden

\begin{tabular}{ccc}
\hline Jenis Kelamin & Jumlah & \% \\
\hline Pria & 48 & 40 \\
Wanita & 72 & 60 \\
\hline Umur & Jumlah & $\mathbf{\%}$ \\
\hline Umur $\leq 20$ & 23 & 19,17 \\
Umur $21-30$ & 45 & 37,5 \\
Umur $31-40$ & 36 & 30 \\
Umur $\geq 41$ & 16 & 13,33 \\
\hline Pekerjaan & Jumlah & \% \\
\hline Pelajar/Mahasiswa & 38 & 31,67 \\
Kary. Swasta & 43 & 35,83 \\
PNS & 24 & 20 \\
Wirausaha & 10 & 8,33 \\
Lainnya & 5 & 4,17 \\
\hline Pendidikan & Jumlah & $\mathbf{\%}$ \\
\hline SMP, SMA & 34 & 28,33 \\
D3 & 28 & 23,33 \\
Sarjana & 66 & 55 \\
\hline Belanja Online & Jumlah & $\%$ \\
\hline 1 -5 kali & 21 & 17,5 \\
6 - 10 kali & 53 & 44,17 \\
$\geq 11$ kali & 46 & 38,33 \\
\hline & &
\end{tabular}

\section{Hasil Penelitian}

Kualitas Data

Uji Validitas

Dari hasil pengujian validitas diperoleh hasil sebagai berikut:

Tabel 2 HasilUji Validitas

\begin{tabular}{cccccc}
\hline Pernyataan & Fitur & $\begin{array}{c}\text { Praktik } \\
\text { Terbaik }\end{array}$ & $\begin{array}{c}\text { Peningkatan } \\
\text { e-commerce }\end{array}$ & $\begin{array}{c}\mathbf{R} \\
\text { Tabel }\end{array}$ & Kesimpulan \\
\hline Instrumen 1 & 0,223 & 0,416 & 0,795 & 0.1793 & Valid \\
Instrumen 2 & 0,487 & 0,621 & 0,382 & 0.1793 & Valid \\
Instrumen 3 & 0,222 & 0,687 & 0,627 & 0.1793 & Valid \\
Instrumen 4 & 0,395 & 0,671 & 0,776 & 0.1793 & Valid \\
Instrumen 5 & 0,410 & 0,699 & 0,618 & 0.1793 & Valid \\
Instrumen 6 & 0,556 & 0,716 & 0,612 & 0.1793 & Valid \\
Instrumen 7 & 0,377 & 0,771 & 0,533 & 0.1793 & Valid \\
\hline
\end{tabular}


Uji Reliabilitas

Dari hasil uji Reliabilitas diperoleh hasil sebagai berikut:

Tabel 3 Hasil Uji Reliabilitas

\begin{tabular}{lccc}
\hline \multicolumn{1}{c}{ Variabel } & $\begin{array}{c}\text { Cronbach } \\
\text { Alpha }\end{array}$ & $\begin{array}{c}\text { Nilai Kritis } \\
(\boldsymbol{\alpha}=\mathbf{5 \%})\end{array}$ & Keterangan \\
\hline Fitur & 0,638 & 0,6 & Reliabel \\
$\begin{array}{l}\text { Praktik } \\
\text { Terbaik }\end{array}$ & 0,777 & 0,6 & Reliabel \\
$\begin{array}{l}\text { Peningkatan e- } \\
\text { commerce }\end{array}$ & 0,737 & 0,6 & Reliabel \\
\hline
\end{tabular}

\section{Analisa Hasil Penelitian}

Dari hasil uji T dan uji F diperoleh hasil sebagai berikut:

Tabel 4 Hasil Uji t \& F

\begin{tabular}{lccccccc}
\hline $\begin{array}{c}\text { Hubungan } \\
\text { Variabel }\end{array}$ & $\mathbf{R}$ & $\begin{array}{c}\mathbf{R} \\
\text { Square }\end{array}$ & Konstanta & Coef. B & $\begin{array}{c}\mathbf{t} \\
\text { hitung }\end{array}$ & Sig & $\boldsymbol{\alpha}$ \\
\cline { 2 - 7 } & & & & 0,317 & 4,150 & & \\
\hline $\begin{array}{l}\text { Fitur } \\
\text { Praktek }\end{array}$ & 0,835 & 0,697 & 4,257 & 0,560 & 8,801 & 0,00 & 0,05 \\
Terbaik & & & & & & \\
\hline
\end{tabular}

Pengujian Signifikansi

F hitung $>$ F table $: \mathbf{1 3 4 , 4 3 5}>\mathbf{3 . 0 7}$

Keterangan : Variabel Dependen : Peningkatan E-Commerce

Sumber : Data diolah

Nilai $\mathrm{F}$ hitung 134,435 > F tabel 3.07, sehingga dapat disimpulkan bahwa H3 diterima yang berarti terdapat pengaruh fitur dan praktik terbaik terhadap peningkatan $e$ commerce.

Nilai $\mathrm{R}^{2}$ sebesar 0,697 mempunyai arti bahwa kontribusi diberikan fitur instagram dan praktik terbaik dari instagram terhadap peningkatan e-Commerce melalui instagram sebesar $69,7 \%$

Hasil pengolahan data yang tampak pada tabel 4 diperoleh persamaan regresi adalah sebagai berikut: $\hat{Y}=4,257+0,317\left(X_{1}\right)+0,560\left(X_{2}\right)$. Tanda positif pada koefisien menunjukkan bahwa ada hubungan positif dari variabel fitur instagram yang menyebabkan kenaikan sebesar 0,317 terhadap peningkatan e-commerce melalui instagram. Begitupula dengan praktik terbaik instagram sebesar 0,560 berati terdapat hubungan yang searah pada peningkatan penjualan online melalui instagram. 
1) Pengaruh fitur terhadap peningkatan e-commerce (H1)

Diperolehi nilai signifikansi untuk pengaruh fitur terhadap peningkatan e-commerce adalah sebesar $0,00<0,05$ dan nilai $t$ hitung 4,150>t tabel 0,9804 , sehingga dapat disimpulkan bahwa $\mathrm{H} 1$ diterima yang berarti terdapat pengaruh fitur terhadap peningkatan e-commerce.

\section{2) Pengaruh praktik terbaik terhadap peningkatan e-commerce (H2)}

Diperoleh nilai signifikansi untuk pengaruh praktik terbaik terhadap peningkatan e-commerce adalah sebesar $0,000<0,05$ dan nilai t hitung 8,801> t tabel 0,9804, sehingga dapat disimpulkan bahwa $\mathrm{H} 2$ diterima yang berarti terdapat pengaruh praktik terbaik terhadap peningkatan $e$-commerce.

3) Pengaruh fitur dan praktik terbaik terhadap peningkatan e-commerce (H3)

Berdasarkan Tabel 4, diketahui nilai signifikansi untuk pengaruh fitur dan praktik terbaik terhadap peningkatan $e$-commerce adalah sebesar $0,000<0,05$.

\section{KESIMPULAN}

\section{Kesimpulan}

Setelah dilakukan pengolahan data maka hasil penelitian menyatakan bahwa fitur dan praktik terbaik instagram memberikan manfaat, pengaruh positif, dan signifikan terhadap peningkatan e-commerce melalui instagram.

\section{Saran}

Melihat hasil penelitian dan pembahasan, variabel fitur instagram dapat terus dikembangkan. Fitur-fitur unik yang diharapkan dapat mencuri perhatian pengguna social media, sehingga dapat menarik konsumen untuk membeli. Fitur-fitur ini membantu mereka untuk semakin banyak berinteraksi dengan para pelanggan dan memberikan sentuhan yang berbeda.Variabel praktik terbaik yang terus dikembangkan bukan saja dapat menambah follower yang dapat membantu upaya promosi dan kemudian akan menarik pembeli untuk membeli produk kita sehingga transaksi online akan terus meningkat.

\section{DAFTAR PUSTAKA}

Abyad, Abdulrazak. 2017. Importance of Consumer Trust in e-commerce. Middle East Journal of Business. Vol 12.

Ade Irma, 2017, Peran Instagram Sebagai Media Komunikasi Pemasaran Bisnis Online (Studi Deskriptif Kualitatif Pada Bisnis Online Beauty home shop). Jurnal Online Kinesik Vol. 4 No. 2 (2017)

Anshari, Rindy. 2013. Strategi Komunikasi Pemasaran Melalui Media Online Dan TingkatKepuasan Membeli (Studi Korelasional tentang Strategi Penjualan Produk Fashion melalui" Instagram" terhadap Kepuasan Membeli Mahasiswa FISIP USU). Jurnal Ilmu Komunikasi.FLOW. Vol 2 (7).

Aprilya, Trias. 2017. Strategi Komunikasi Pemasaran Melalui Instagran Dalam Meningkatkan Kepercayaan Customer Di Samarinda. E-Journal Ilmu Komunikasi. Vol 5 (1). 
Budi Astuti, Azhalia Pramesthi Putri, 2018 Analysis on the Effect of Instagram Use on Consumer Purchase Intensity. Review of Integrative Business and Economics Research, Vol. 7, Supplementary Issue 2

Carter B, Levy J, Facebook Marketing: Leveraging Facebook Features for Your Marketing Campaigns, 1st ed., Que Pub, 2011.

Celeste See-Pui Ng \& Wil liam Yu Chung Wang. 2013 Best Practices In Managing Social Media For Business. Thirty Fourth International Conference on Information Systems, Milan 2013

Dan Zarrella, 2009. The Social Media Marketing Book. O'Reilly Media. ISBN-10 9780596806606

Guide, Social. "Social Media for Business: A Marketer's Guide". Business News Daily. N.p., 2017. Web. 10 Mar. 2017.

Hua Hu, Ding Lin, 2013 Feature Analysis of the Social Media, International Workshop on Computer Science in Sports (IWCSS 2013)

Jan Zimmerman and Deborah Ng. 2017, Social Media Marketing All In One For Dummies 4th Edition, Published by: John Wiley \& Sons, Inc., 111 River Street, Hoboken, NJ 07030-5774, www.wiley.com, Copyright (C) 2017 by John Wiley \& Sons, Inc., Hoboken, New Jersey

Manohar Singh, Gobindbir Singh.2018 Impact of Social Media on E-commerce, International Journal of Engineering \& Technology, 7 (2.30) (2018) 21-26, Website: www.sciencepubco.com/index.php/IJET

Rahmawati, Dewi. 2016. "Pemilihan dan Pemanfaatan Instagram Sebagai Media Komunikasi Pemasaran Online (Studi Desktiptif Kualitatif pada Akun Instagram @ FreezyBrowniezz. Skripsi. Fakultas Ilmu Sosisal dan Humaniora Universitas Islam Negri Sunan Kalijaga,Yogyakarta.

Schivinski, Bruno, and Dariusz Dabrowski. "The effect of social me- dia communication on consumer perceptions of brands." Journal of Marketing Communications 22.2 (2016): 189-214 